\title{
Aggression in the Workplace Makes Social Distancing Difficult
}

Keisuke Kokubun ( $\sim$ kokubun@eri.jspmi.or.jp)

Economic Research Institute, Japan Society for the Promotion of Machinery Industry https://orcid.org/0000-0002-7440-5049

Yoshinori Yamakawa

Kyoto Daigaku

\section{Research article}

Keywords: coronavirus disease (COVID-19), social distancing, physical proximity, aggression, explanatory factor analysis, O*NET

Posted Date: February 26th, 2021

DOl: https://doi.org/10.21203/rs.3.rs-273911/v1

License: (c) (i) This work is licensed under a Creative Commons Attribution 4.0 International License. Read Full License 


\section{Abstract}

Background: The coronavirus disease (COVID-19) is still spreading. While social distancing has attracted attention as a measure to prevent the spread of infection, some occupations find it difficult to practice it. Therefore, we decided to investigate the differences in the ease of practicing social distancing depending on the occupation using the data on $\mathrm{O} N \mathrm{NET}$, an occupational information site.

Methodology: Eight factors were extracted by performing exploratory factor analysis based on certain rules while eliminating arbitrariness as much as possible: adverse conditions, leadership, information processing, response to aggression, mechanical movement, autonomy, communication with the outside, and horizontal teamwork.

Results: Adverse conditions, response to aggression, and horizontal teamwork had a positive correlation with physical proximity, while information processing, mechanical movement, autonomy, and communication with the outside had a negative correlation with it. Furthermore, multiple regression analysis showed that response to aggression, not just teamwork, as assumed in previous studies, had the greatest influence on physical proximity.

Conclusion: To maintain social distancing, it is necessary to constrain aggression in the workplace.

\section{Introduction}

The coronavirus disease (COVID-19) continues to spread steadily. As of this writing, on August 8, 2020, there are 19,382,107 infected people worldwide. ${ }^{1}$ The recommended practice for preventing infection is social distancing-that is, maintaining a specific physical distance between people. ${ }^{2}$ However, it is not easy to practice this in all jobs; hence there is growing research to clarify the relationship between work characteristics and social distancing. ${ }^{3,4,5,6}$ Such research can provide valuable hints about and insights into the new industrial structure in the post-COVID era. However, this does not mean that the research conducted is problem-free-there exists a lack of clarity on how to select the appropriate factors influencing the above-mentioned relationship.

Therefore, this study used the 98 items recorded under Work Context and Work Activities on O*NET, an occupational information site in the United States, to perform factor analysis while eliminating arbitrariness as much as possible. Then, after creating an independent variable from the extracted factors, a regression analysis using physical proximity as the dependent variable was performed. The purpose of this study was to find the factors influencing social distancing (physical proximity as a proxy variable). In addition, Koren \& Pető's teamwork, customer, and presence, ${ }^{6}$ and Dingel \& Neiman's remote working ${ }^{4}$ were used as independent variables to verify whether these are useful as determinants of social distancing.

\section{A Review Of Previous Studies}

Research to clarify the relationship between work characteristics and social distancing has been gathering pace. 3,4,5,6 Among the studies on this topic, the Social Distancing Index developed by Koren \& Petö ${ }^{6}$ and Remote Working Index developed by Dingel \& Neiman ${ }^{4}$ have 49 and 266 citations respectively (as of August 8, 2020, computed by Google Scholar); however, there is some arbitrariness in the creation of indicators. The Social Distancing Index classifies 14 questionnaire items recorded on $0 *$ NET under teamwork, customer, and presence, based on the hypothesis that the three factors influencing social distancing are teamwork, customer, and presence. The Remote Working Index also creates variables based on the assumption that the 17 items related to outdoor work, etc., recorded on $0 *$ NET, influence the executability of remote work. However, neither index clearly shows the criteria for classification. Both were probably classified by the authors' eyes.

There is, therefore, no guarantee that the respondents to the questionnaire responded as the researchers intended. For example, teamwork from Koren \& Petö 6 includes items related to leadership. Perhaps there is a difference in the feasibility of social distancing between the vertical and horizontal teams. Further, there is a problem in the correlation between "Work Context - Physical Proximity", the items seemingly closest to the feasibility of social distancing and remote work among those recorded on $0 * \mathrm{NET}$, and each item has not been verified.

Therefore, in this study, to eliminate arbitrariness as much as possible, some factors common to various occupations were extracted by performing exploratory factor analysis based on certain rules. Based on those factors, we showed the factors determining physical proximity by performing multiple regression analysis using the constructed independent variables. At the same time, we analyzed teamwork, customer, and presence from Koren \& Petö 6 and remote working from Dingel \& Neiman ${ }^{4}$ as independent variables, to verify whether these are useful as determinants of social distancing.

\section{Methodology}

Among the questionnaire results for 968 occupations posted on O*NET (https://www.onetonline.org/), we used the 98 items recorded under Work Context and Work Activities, which were used by Koren \& Pető, ${ }^{6}$ Dingel \& Neiman, ${ }^{4}$ and others in their studies. Importance and level are recorded under Work Activities, but in this study, importance was used according to previous research for optimum clarity. All items take a number from 0 to 100 , indicating frequency and importance. The criterion for factor extraction was an eigenvalue of 1 or more, and the factor load was calculated after performing varimax rotation using the main factor method. After that, items with a factor load of less than 0.4 and of 0.4 or higher on a plurality of factors were excluded, and factor analysis was performed again using the same criteria. This process was repeated until there were no items whose factor loads were less than 0.4 and 0.4 or higher on plural factors. Here, we followed the idea of Stevens, ${ }^{7}$ who suggests using a cut-off of 0.4 , irrespective of sample size, for interpretative purposes. After establishing the factor structure, we presented a simple hypothesis, which should be verified, and performed regression analysis using the variables comprising each factor as the independent variable and physical proximity as the dependent variable to analyze the factors influencing social distancing. 
As a result of repeating the factor analysis six times using the above method, as shown in Table 1, eight factors comprising 46 items were extracted. Note that the sentences listed are not the questions themselves, but the topic of the questions. Details of questions and options can be referred to on $0 * N E T$; therefore, they are omitted in this paper. However, to give an example, the question corresponding to the topic at the top of the table for better clarity, "Work Context - Very Hot or Cold Temperatures," is "How often does this job require working in very hot (above 90 degrees F) or very cold (below 32 degrees F) temperatures?", and the options are "Never," "Once a year or more but not every month," "Once a month or more but not every week," "Once a week or more but not every day," and "Every day," with $0,25,50,75$, and 100 points assigned to each, to calculate the average value for each occupation. Furthermore, physical proximity used as a dependent variable in this study was selected from "I don't work near other people (beyond 100ft)," "I work with others but not closely (e.g., private office)," "Slightly close (e.g., shared office)," "Moderately close (at arm's length)," and "Very close (nearly touching)" for the question "To what extent does this job require the worker to perform job tasks in close physical proximity to other people?" and was assigned a value from 0 to 100 when totaling.

Based on the contents of the included items, the factors were named as adverse conditions, leadership, information processing, response to aggression, mechanical movement, autonomy, communication with the outside, and horizontal teamwork. Physical proximity was not included in any of these variables because it loaded on multiple factors in the first factor analysis. As indicated by the symbol (R) at the end of the sentence, four adverse conditions overlapped with remote working from Dingel \& Neiman, ${ }^{4}$ and as shown by $(P)$, one of these overlapped with presence from Koren \& Petö. ${ }^{6}$ Similarly, three of leadership and one of horizontal teamwork overlapped with teamwork from Koren \& Petö ${ }^{6}$ as shown by $(T)$. One of response to aggression overlapped with presence from Koren \& Petö ${ }^{6}$ as shown in $(P)$. There were no duplicate items with customer from Koren \& Pető. ${ }^{6}$ Overall, nine of the 46 items, or $19.6 \%$, overlapped with those from either or both Dingel \& Neiman ${ }^{4}$ and Koren \& Pető. ${ }^{6}$ 
Table 1

Results of exploratory factor analysis

\begin{tabular}{|c|c|c|c|c|c|c|c|c|}
\hline Item & $\begin{array}{l}\text { Adverse } \\
\text { Conditions }\end{array}$ & Leadership & $\begin{array}{l}\text { Information } \\
\text { Processing }\end{array}$ & $\begin{array}{l}\text { Response } \\
\text { to } \\
\text { Aggression }\end{array}$ & $\begin{array}{l}\text { Mechanical } \\
\text { Movement }\end{array}$ & Autonomy & $\begin{array}{l}\text { Communication } \\
\text { with the } \\
\text { Outside }\end{array}$ & $\begin{array}{l}\text { Horizontal } \\
\text { Teamwork }\end{array}$ \\
\hline $\begin{array}{l}\text { Work Context - Very Hot or Cold } \\
\text { Temperatures }\end{array}$ & 0.916 & 0.003 & -0.110 & 0.031 & 0.005 & -0.101 & 0.007 & -0.127 \\
\hline $\begin{array}{l}\text { Work Context - Extremely Bright } \\
\text { or Inadequate Lighting }\end{array}$ & 0.880 & -0.086 & -0.018 & 0.102 & 0.054 & -0.047 & -0.040 & 0.043 \\
\hline $\begin{array}{l}\text { Work Activities - Operating } \\
\text { Vehicles, Mechanized Devices, or } \\
\text { Equipment }(P)(R)\end{array}$ & 0.863 & 0.025 & -0.042 & 0.090 & 0.054 & -0.024 & -0.020 & -0.189 \\
\hline $\begin{array}{l}\text { Work Context - Outdoors, } \\
\text { Exposed to Weather (R) }\end{array}$ & 0.857 & 0.035 & 0.008 & 0.116 & -0.158 & 0.023 & 0.328 & -0.058 \\
\hline $\begin{array}{l}\text { Work Context - Exposed to } \\
\text { Hazardous Equipment }\end{array}$ & 0.851 & -0.011 & -0.111 & -0.124 & 0.197 & -0.011 & -0.261 & -0.052 \\
\hline $\begin{array}{l}\text { Work Context - Exposed to High } \\
\text { Places }\end{array}$ & 0.834 & -0.007 & -0.033 & -0.102 & 0.023 & -0.023 & 0.033 & 0.273 \\
\hline $\begin{array}{l}\text { Work Context - Indoors, Not } \\
\text { Environmentally Controlled }\end{array}$ & 0.833 & 0.049 & -0.043 & -0.090 & 0.021 & 0.002 & 0.014 & -0.054 \\
\hline $\begin{array}{l}\text { Work Context - In an Open Vehicle } \\
\text { or Equipment }\end{array}$ & 0.824 & 0.016 & -0.080 & -0.075 & -0.015 & -0.044 & -0.005 & -0.032 \\
\hline $\begin{array}{l}\text { Work Context - Spend Time } \\
\text { Climbing Ladders, Scaffolds, or } \\
\text { Poles }\end{array}$ & 0.787 & -0.007 & -0.079 & -0.133 & -0.028 & -0.034 & 0.023 & 0.262 \\
\hline $\begin{array}{l}\text { Work Context - Exposed to Minor } \\
\text { Burns, Cuts, Bites, or Stings (R) }\end{array}$ & 0.775 & -0.036 & -0.234 & 0.002 & 0.069 & -0.019 & -0.258 & -0.126 \\
\hline $\begin{array}{l}\text { Work Context - Outdoors, Under } \\
\text { Cover (R) }\end{array}$ & 0.774 & 0.069 & 0.040 & 0.019 & -0.164 & 0.045 & 0.355 & 0.023 \\
\hline $\begin{array}{l}\text { Work Context - Exposed to Whole } \\
\text { Body Vibration }\end{array}$ & 0.761 & -0.030 & -0.065 & -0.016 & -0.020 & -0.051 & -0.108 & 0.076 \\
\hline $\begin{array}{l}\text { Work Context - Sounds, Noise } \\
\text { Levels Are Distracting or } \\
\text { Uncomfortable }\end{array}$ & 0.718 & -0.060 & -0.128 & 0.126 & 0.272 & -0.141 & -0.299 & 0.070 \\
\hline $\begin{array}{l}\text { Work Context - Spend Time } \\
\text { Keeping or Regaining Balance }\end{array}$ & 0.705 & -0.022 & -0.222 & 0.155 & -0.109 & -0.083 & -0.142 & 0.076 \\
\hline $\begin{array}{l}\text { Work Context - Indoors, } \\
\text { Environmentally Controlled }\end{array}$ & -0.697 & 0.124 & 0.237 & 0.041 & 0.126 & 0.113 & 0.125 & 0.171 \\
\hline Work Context - Work Schedules & 0.468 & -0.004 & -0.123 & -0.099 & -0.284 & 0.066 & 0.159 & -0.090 \\
\hline $\begin{array}{l}\text { Work Activities - Guiding, } \\
\text { Directing, and Motivating } \\
\text { Subordinates }(T)\end{array}$ & 0.045 & 0.894 & 0.192 & 0.053 & -0.016 & 0.060 & -0.004 & 0.109 \\
\hline $\begin{array}{l}\text { Work Activities - Coordinating the } \\
\text { Work and Activities of Others }(T)\end{array}$ & 0.070 & 0.855 & 0.188 & 0.073 & -0.014 & -0.013 & 0.066 & 0.194 \\
\hline $\begin{array}{l}\text { Work Activities - Staffing } \\
\text { Organizational Units }\end{array}$ & -0.088 & 0.833 & 0.141 & 0.069 & 0.041 & 0.063 & 0.169 & -0.015 \\
\hline $\begin{array}{l}\text { Work Activities - Developing and } \\
\text { Building Teams }(T)\end{array}$ & -0.057 & 0.819 & 0.262 & 0.169 & -0.058 & -0.067 & 0.061 & 0.207 \\
\hline $\begin{array}{l}\text { Work Activities - Coaching and } \\
\text { Developing Others }\end{array}$ & -0.065 & 0.796 & 0.238 & 0.160 & -0.190 & 0.073 & -0.190 & 0.125 \\
\hline $\begin{array}{l}\text { Work Activities - Monitoring and } \\
\text { Controlling Resources }\end{array}$ & 0.043 & 0.733 & 0.095 & -0.083 & 0.100 & 0.169 & 0.244 & -0.114 \\
\hline $\begin{array}{l}\text { Work Activities - Scheduling Work } \\
\text { and Activities }\end{array}$ & -0.036 & 0.678 & 0.307 & 0.008 & -0.086 & 0.237 & 0.188 & -0.030 \\
\hline $\begin{array}{l}\text { Work Activities - Training and } \\
\text { Teaching Others }\end{array}$ & -0.009 & 0.624 & 0.321 & 0.089 & -0.204 & 0.063 & -0.303 & 0.088 \\
\hline $\begin{array}{l}\text { Work Activities - Judging the } \\
\text { Qualities of Things, Services, or } \\
\text { People }\end{array}$ & 0.037 & 0.539 & 0.338 & 0.097 & 0.033 & 0.170 & -0.149 & -0.136 \\
\hline
\end{tabular}

Note(s): If the factor load is 0.4 or higher, italic and bold type. 


\begin{tabular}{|c|c|c|c|c|c|c|c|c|}
\hline Item & $\begin{array}{l}\text { Adverse } \\
\text { Conditions }\end{array}$ & Leadership & $\begin{array}{l}\text { Information } \\
\text { Processing }\end{array}$ & $\begin{array}{l}\text { Response } \\
\text { to } \\
\text { Aggression }\end{array}$ & $\begin{array}{l}\text { Mechanical } \\
\text { Movement }\end{array}$ & Autonomy & $\begin{array}{l}\text { Communication } \\
\text { with the } \\
\text { Outside }\end{array}$ & $\begin{array}{l}\text { Horizontal } \\
\text { Teamwork }\end{array}$ \\
\hline $\begin{array}{l}\text { Work Activities - Analyzing Data } \\
\text { or Information }\end{array}$ & -0.260 & 0.257 & 0.790 & -0.179 & 0.068 & 0.113 & 0.102 & 0.051 \\
\hline $\begin{array}{l}\text { Work Activities - Processing } \\
\text { Information }\end{array}$ & -0.248 & 0.209 & 0.788 & -0.098 & 0.261 & 0.006 & 0.104 & 0.002 \\
\hline $\begin{array}{l}\text { Work Activities - Interpreting the } \\
\text { Meaning of Information for } \\
\text { Others }\end{array}$ & -0.281 & 0.347 & 0.759 & 0.007 & -0.135 & 0.150 & 0.020 & 0.128 \\
\hline $\begin{array}{l}\text { Work Activities - Updating and } \\
\text { Using Relevant Knowledge }\end{array}$ & -0.262 & 0.298 & 0.741 & -0.028 & -0.010 & 0.237 & 0.066 & 0.079 \\
\hline $\begin{array}{l}\text { Work Activities - Getting } \\
\text { Information }\end{array}$ & -0.196 & 0.218 & 0.724 & 0.058 & 0.140 & 0.141 & 0.083 & 0.110 \\
\hline $\begin{array}{l}\text { Work Activities - } \\
\text { Documenting/Recording } \\
\text { Information }\end{array}$ & -0.208 & 0.211 & 0.695 & 0.189 & 0.147 & 0.120 & 0.117 & -0.002 \\
\hline $\begin{array}{l}\text { Work Activities - Identifying } \\
\text { Objects, Actions, and Events }\end{array}$ & 0.139 & 0.240 & 0.676 & 0.104 & 0.109 & 0.088 & -0.139 & 0.016 \\
\hline $\begin{array}{l}\text { Work Activities - Evaluating } \\
\text { Information to Determine } \\
\text { Compliance with Standards }\end{array}$ & 0.095 & 0.314 & 0.549 & 0.155 & 0.332 & -0.093 & 0.050 & 0.070 \\
\hline $\begin{array}{l}\text { Work Context - Deal With } \\
\text { Unpleasant or Angry People }\end{array}$ & -0.066 & 0.075 & -0.056 & 0.886 & 0.195 & -0.041 & 0.050 & 0.057 \\
\hline $\begin{array}{l}\text { Work Context - Deal With } \\
\text { Physically Aggressive People (R) }\end{array}$ & 0.053 & 0.094 & 0.064 & 0.817 & -0.051 & -0.029 & -0.040 & -0.009 \\
\hline $\begin{array}{l}\text { Work Context - Frequency of } \\
\text { Conflict Situations }\end{array}$ & -0.043 & 0.284 & 0.108 & 0.738 & 0.195 & 0.126 & 0.127 & 0.210 \\
\hline $\begin{array}{l}\text { Work Context - Importance of } \\
\text { Repeating Same Tasks }\end{array}$ & -0.024 & -0.145 & 0.059 & 0.204 & 0.694 & -0.122 & 0.054 & 0.024 \\
\hline $\begin{array}{l}\text { Work Context - Importance of } \\
\text { Being Exact or Accurate }\end{array}$ & -0.084 & -0.121 & 0.273 & -0.035 & 0.686 & 0.064 & -0.057 & 0.034 \\
\hline $\begin{array}{l}\text { Work Context - Degree of } \\
\text { Automation }\end{array}$ & -0.053 & -0.049 & 0.026 & -0.004 & 0.524 & -0.270 & 0.080 & -0.019 \\
\hline Work Context - Time Pressure & 0.081 & 0.072 & 0.076 & 0.062 & 0.460 & 0.088 & -0.041 & 0.089 \\
\hline $\begin{array}{l}\text { Work Context - Freedom to Make } \\
\text { Decisions }\end{array}$ & -0.069 & 0.166 & 0.271 & 0.020 & -0.137 & 0.815 & 0.064 & 0.011 \\
\hline $\begin{array}{l}\text { Work Context - Structured versus } \\
\text { Unstructured Work }\end{array}$ & -0.207 & 0.209 & 0.239 & -0.048 & -0.074 & 0.772 & 0.127 & 0.044 \\
\hline Work Context - Telephone & -0.190 & 0.201 & 0.313 & 0.190 & 0.184 & 0.394 & 0.597 & 0.243 \\
\hline $\begin{array}{l}\text { Work Activities - Communicating } \\
\text { with Persons Outside } \\
\text { Organization }\end{array}$ & -0.253 & 0.350 & 0.399 & 0.169 & -0.091 & 0.250 & 0.515 & 0.031 \\
\hline $\begin{array}{l}\text { Work Context - Work With Work } \\
\text { Group or Team }(\mathrm{T})\end{array}$ & -0.008 & 0.362 & 0.170 & 0.270 & 0.212 & -0.103 & 0.041 & 0.496 \\
\hline $\begin{array}{l}\text { Work Context - Face-to-Face } \\
\text { Discussions }\end{array}$ & -0.004 & 0.251 & 0.223 & 0.156 & 0.154 & 0.223 & 0.069 & 0.470 \\
\hline
\end{tabular}

$(T)$ and $(P)$ indicate that they overlap with teamwork and presence from Koren \& Pető. ${ }^{6}$

(R) indicates overlap with remote working from Dingel \& Neiman. ${ }^{4}$

\section{Hypothesis}

Of the eight factors, leadership, response to aggression, and horizontal teamwork involve relationships with people and are expected to require physical proximity. Thus, the following hypothesis was derived.

H1: Leadership, response to aggression, and horizontal teamwork have a positive correlation with physical proximity. 
On the other hand, information processing, autonomy, mechanical movement, and communication with the outside are considered to be aspects of jobs that do not require physical contact with people. Thus, the following hypothesis was derived.

$\mathrm{H} 2$ : Information processing, autonomy, mechanical movement, and communication with the outside have a negative correlation with physical proximity.

In addition, adverse conditions does not generally require closeness to people, but such closeness will come into play if the job requires more than one person in case of an unexpected situation. Therefore, the following hypothesis was derived.

H3: Adverse conditions has a positive correlation with physical proximity.

What has the strongest correlation with physical proximity? Information processing, autonomy, mechanical movement, and communication with the outside do not require physical proximity, and at the same time, they do not actively avoid physical proximity. Therefore, it is expected that any one from leadership, response to aggression, and horizontal teamwork, which involve relationships with people, has the strongest correlation with physical proximity-among these, leadership has the weakest correlation as it can be demonstrated over long distances depending on the content. Virtually reconstructing the reporting line should not be too difficult if the relationship between the top and bottom is clear. There is also a study showing that the virtual is more effective than face-toface for some kinds of leadership. ${ }^{8}$ In this regard, horizontal teamwork involves a more horizontal relationship, so it is considered that in this case physical proximity is more important than leadership. This is because who takes the initiative depends on the tasks that change daily. In addition, when someone performs many tasks, adjustments are frequently made to reduce the tasks. However, with proper feedback and procedural justifications from the boss, the adverse effects of role ambiguity can be significantly reduced. ${ }^{9,10}$ Therefore, it is response to aggression that is expected to have the strongest correlation with physical proximity. This is because collaboration with a person bad at emotional control is likely to induce an unexpected situation, so it is considered necessary to have such people in close proximity and to cooperate with others around them. Previous studies have shown that maintaining physical proximity with students, for example, is necessary for teachers to turn their negative consciousness into a positive one. ${ }^{11}$ Thus, the following hypothesis was derived.

H4: Response to aggression has the strongest positive correlation with physical proximity.

\section{Analysis And Results}

Table 2 presents the descriptive statistics-in addition to the above eight variables, physical proximity; teamwork, customer, and presence from Koren \& Petö; 6 and remote working from Dingel \& Neiman ${ }^{4}$ are listed with their values and correlations as per the author's calculation. In general, 0.7 or higher is considered to be an acceptable reliability coefficient, ${ }^{12}$ but several researchers have accepted 0.6 or more. ${ }^{13,14}$ According to the latter criterion, all eight variables were acceptable, but according to the former, mechanical movement and horizontal teamwork were unacceptable. Therefore, we prepared a three-item version without work context-time pressure for mechanical movement, and a three-item version with work context-coordinate or lead others for horizontal teamwork, which had been dropped in the first factor analysis for being the same as the other two items but loaded on other factors. After confirming that the reliability coefficients of these variables were 0.7 or higher, they were used for the following analysis alternatively (the result is omitted because it did not make a big difference).

Looking at the magnitude of the correlation coefficient, all except leadership and mechanical movement showed a statistically significant correlation with physical proximity at the $5 \%$ level. However, values exceeding 0.1 , which is the standard value for "small" by Cohen (1988), were observed in three variables: response to aggression $(r=0.456, p<0.01)$, autonomy $(r=-0.130, p<0.05)$, and horizontal teamwork $(r=0.306, p<0.01)$. Of these, only response to aggression and horizontal teamwork exceeded the standard value of 0.3 for "medium" by Cohen (1988). ${ }^{15}$ Moreover, as shown in the table, among the three from Koren \& Petö, ${ }^{6}$ customer $(r=0.415, p<0.01)$ and presence $(r=0.197, p<0.01)$ exceeded 0.1 , with only customer exceeding 0.3 . Dingel \& Neiman's remote working 4 $(r=-0.356, p<0.01)$ also exceeded 0.3. However, the coefficient of Koren \& Petö's teamwork $(r=0.098, p<0.01)$ was below 0.1 . This is probably because, as described at the beginning, items that represent horizontal teamwork and those that represent vertical teamwork are mixed in the variable.

Table 3 shows the results of regression analysis. Eight independent variables were individually inputted into the regression equation. Response to aggression $(\beta=0.456, p<0.01)$ and horizontal teamwork $(\beta=0.306, p<0.01)$ showed a significant positive correlation, supporting $H 1$. Information processing $(\beta=-0.085, p$ $<0.01)$, autonomy $(\beta=-0.129, p<0.01)$, and communication with the outside $(\beta=-0.065, p<0.05)$ showed a significant negative correlation, supporting $H 2$. Furthermore, a significant positive correlation was observed in adverse conditions $(\beta=0.074, p<0.05)$, supporting H3. However, regarding leadership ( $\beta=$ $0.057, p>0.05)$, where a positive correlation was expected, and mechanical movement $(\beta=0.001, p>0.05)$, where a negative correlation was expected, a significant correlation was not found at the $5 \%$ level. Comparing the adjusted R-squared value, response to aggression was the largest at 0.207 , followed by horizontal teamwork at 0.093 and autonomy at 0.016 . This shows that response to aggression has the greatest influence on social distancing, and it can thus be said that this is the result that supports $\mathrm{H} 4$. 
Table 2

Descriptive statistics

\begin{tabular}{|c|c|c|c|c|c|c|c|c|c|c|c|}
\hline & Mean & SD & $\mathbf{a}$ & $\begin{array}{l}\text { Physical } \\
\text { Proximity }\end{array}$ & $\begin{array}{l}\text { Adverse } \\
\text { Conditions }\end{array}$ & Leadership & $\begin{array}{l}\text { Information } \\
\text { Processing }\end{array}$ & $\begin{array}{l}\text { Response } \\
\text { to } \\
\text { Aggression }\end{array}$ & $\begin{array}{l}\text { Mechanical } \\
\text { Movement }\end{array}$ & Autonomy & $\begin{array}{l}\text { Comm } \\
\text { with th } \\
\text { Outsid }\end{array}$ \\
\hline $\begin{array}{l}\text { Physical } \\
\text { Proximity }\end{array}$ & 60.300 & 16.875 & & & & & & & & & \\
\hline $\begin{array}{l}\text { Adverse } \\
\text { Conditions }\end{array}$ & 18.542 & 17.538 & 0.929 & $0.074^{\star}$ & & & & & & & \\
\hline Leadership & 48.440 & 11.806 & 0.939 & 0.056 & -0.058 & & & & & & \\
\hline $\begin{array}{l}\text { Information } \\
\text { Processing }\end{array}$ & 66.133 & 11.940 & 0.923 & $-0.085^{\star \star}$ & $-0.307 * \star$ & $0.553^{\star \star}$ & & & & & \\
\hline $\begin{array}{l}\text { Response to } \\
\text { Aggression }\end{array}$ & 36.748 & 12.878 & 0.871 & $0.456^{\star \star}$ & -0.034 & $0.243^{\star \star}$ & $0.146^{\star \star}$ & & & & \\
\hline $\begin{array}{l}\text { Mechanical } \\
\text { Movement }\end{array}$ & 58.955 & 9.699 & 0.694 & 0.001 & -0.038 & $-0.083^{\star \star}$ & $0.195^{\star \star}$ & $0.186^{\star \star}$ & & & \\
\hline Autonomy & 76.918 & 11.440 & 0.897 & -0.130 ** & $-0.214^{\star \star}$ & $0.349 \star \star$ & $0.417 * \star$ & 0.041 & -0.137 ** & & \\
\hline $\begin{array}{l}\text { Communication } \\
\text { with the } \\
\text { Outside }\end{array}$ & 67.569 & 18.633 & 0.810 & $-0.064^{\star}$ & $-0.314^{\star *}$ & $0.447 * \star$ & $0.585^{\star *}$ & $0.312^{\star \star}$ & $0.084^{* *}$ & $0.534^{\star \star}$ & \\
\hline $\begin{array}{l}\text { Horizontal } \\
\text { Teamwork }\end{array}$ & 84.353 & 8.904 & 0.656 & $0.306^{\star *}$ & -0.052 & $0.438 * *$ & $0.392^{\star \star}$ & $0.373^{\star *}$ & $0.188^{\star \star}$ & $0.155^{\star \star}$ & $0.385^{\star}$ \\
\hline${ }^{\mathrm{a}}$ Teamwork & 55.408 & 12.084 & 0.889 & $0.098^{\star *}$ & $-0.094^{\star \star}$ & $0.933^{* *}$ & $0.588^{\star *}$ & $0.287^{\star \star}$ & -0.024 & $0.288^{\star \star}$ & $0.485^{\star}$ \\
\hline${ }^{\mathrm{a} C}$ ustomer & 53.837 & 14.099 & 0.775 & $0.415^{\star \star}$ & $-0.312^{\star \star}$ & $0.525^{\star \star}$ & $0.412^{\star *}$ & $0.584^{\star \star}$ & $-0.068^{*}$ & $0.363^{\star \star}$ & $0.626^{*}$ \\
\hline apresence & 38.202 & 19.354 & 0.911 & $0.197^{\star *}$ & $0.814^{\star *}$ & -0.040 & -0.258 ** & $-0.064^{*}$ & $0.082^{\star}$ & $-0.272^{* *}$ & $-0.403^{\prime}$ \\
\hline $\begin{array}{l}{ }^{b} \text { Remote } \\
\text { Working }\end{array}$ & 57.767 & 13.832 & 0.914 & -0.356 ** & $-0.838 * \star$ & $-0.067^{\star}$ & $0.176^{\star \star}$ & $-0.147 * \star$ & -0.042 & $0.177^{\star \star}$ & $0.255^{\star}$ \\
\hline
\end{tabular}

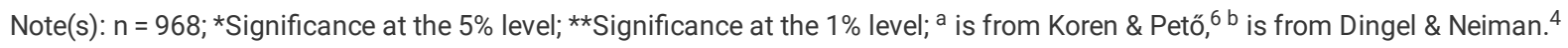

In addition, as shown in the table, all three from Koren \& Petö 6 -teamwork $(\beta=0.098, p<0.01)$, customer $(\beta=0.414, p<0.01)$, and presence $(\beta=0.198, p<0.01)$ -also showed a significant correlation at the $1 \%$ level. However, among them, the adjusted R-squared value of customer was significantly large at 0.171 .

Dingel \& Neiman ${ }^{4}$ 's remote working $(\beta=-0.356, p<0.01)$ also showed a significant correlation at the $1 \%$ level, and its adjusted R-squared value was relatively large at 0.126 . Comparing the magnitude of the partial regression coefficient and the adjusted $\mathrm{R}$-squared value, the order is as follows: response to aggression $\left(\beta=0.456, R^{2}=0.207\right)$, customer $\left(\beta=0.414, R^{2}=0.171\right)$, and remote working $\left(\beta=-0.356, R^{2}=0.126\right)$. 
Table 3

Results of simple regression analysis with physical proximity as the dependent variable

\begin{tabular}{|c|c|c|c|c|c|c|}
\hline Variable & $\beta$ & & $\mathrm{R}^{2}$ & Adj- $R^{2}$ & $F$ & \\
\hline Adverse Conditions & 0.074 & * & 0.006 & 0.005 & 5.367 & * \\
\hline Leadership & 0.057 & & 0.003 & 0.002 & 3.094 & \\
\hline Information Processing & -0.085 & ** & 0.007 & 0.006 & 7.011 & ** \\
\hline Response to Aggression & 0.456 & ** & 0.208 & 0.207 & 253.458 & ** \\
\hline Mechanical Movement & 0.001 & & 0.000 & -0.001 & 0.001 & \\
\hline Autonomy & -0.129 & ** & 0.017 & 0.016 & 16.369 & ** \\
\hline Communication with the Outside & -0.065 & * & 0.004 & 0.003 & 4.056 & * \\
\hline Horizontal Teamwork & 0.306 & ** & 0.094 & 0.093 & 99.691 & ** \\
\hline${ }^{\mathrm{a}}$ Teamwork & 0.098 & ** & 0.010 & 0.009 & 9.348 & ** \\
\hline${ }^{\mathrm{a}}$ Customer & 0.414 & ** & 0.172 & 0.171 & 200.134 & ** \\
\hline apresence & 0.198 & ** & 0.039 & 0.038 & 39.194 & ** \\
\hline${ }^{\mathrm{b}}$ Remote Working & -0.356 & $\star \star$ & 0.127 & 0.126 & 139.189 & ** \\
\hline
\end{tabular}

The first column of Table 4 shows the results of multiple regression analysis using the stepwise method. Response to aggression $(\beta=0.460, p<0.01)$ and horizontal teamwork $(\beta=0.288, p<0.01)$ showed a positive correlation, and information processing $(\beta=-0.096, p<0.01)$, mechanical movement $(\beta=-0.099, p<$ $0.01)$, and communication with the outside $(\beta=-0.254, p<0.01)$ showed a negative correlation. Among them, mechanical movement did not show a significant correlation by simple correlation, but showed a significant negative correlation by multiple regression after controlling the effects of other variables, which is consistent with the hypothesis. On the other hand, adverse conditions and autonomy showed positive and negative correlations in single regression, respectively, but did not show a significant correlation in multiple regression after controlling the effects of other variables. Leadership showed no significant correlation in either single or multiple regression.

Looking at the results of the three items from Koren \& Petö ${ }^{6}$ in the second column of the table, customer $(\beta=0.595, p<0.01)$ and presence $(\beta=0.333$, $p<0.01)$ showed a positive correlation, the same as in simple correlation, but teamwork $(\beta=-0.179, p<0.01)$ showed a negative correlation. It is theoretically difficult to think that teamwork has a negative correlation with physical proximity, so it can be interpreted as a problem of multicollinearity. This indicates that some caution is required when using the three items from Koren \& Petö. ${ }^{6}$ The 14 variables that compose the three from Koren \& Petö ${ }^{6}$ were simply averaged and subtracted from 100 to create one variable Social distancing Index $(a=0.727$, mean value $=50.753$, standard deviation $=9.085)$ following the method of Crowley \& Doran, ${ }^{4}$ and the relationship with physical proximity was examined. Although the problem of multicollinearity was solved, the adjusted R-squared value dropped significantly $\left(\beta=0.437, p<0.01, R^{2}=0.190\right)$.

Therefore, in the third column, the results of a regression analysis performed on a variable group in which customer and remote working, whose adjusted Rsquared value for single regression exceeds 0.13 -the "medium" level ${ }^{15}$ - are added to the first column model as shown. In addition to customer and remote working, four of the five variables shown in the first column, except mechanical movement, are significant. However, the magnitude of the partial correlation coefficient is different between the first and third columns, and it seems that there is a problem of multicollinearity. This is understandable considering that many of the items that make up customer and remote working were excluded during the exploratory factor analysis due to the load on multiple factors. Despite this problem, the fact that the variables in the first column, including response to aggression, became significant even after controlling for the impact of customer and remote working indicates the robustness of the model in the first column. For reference, the adjusted R-squared values for all the three models in Table 4-0.319, 0.293, and 0.491-exceed 0.26, the "large" level. ${ }^{15}$ Among them, the value of the mixed model in the third column is the highest. Therefore, although it is worrisome that the distortion of the partial correlation coefficient impairs the accuracy of the influence of individual variables, the mixed model in the third column is considered to be useful for predicting the feasibility of social distancing more accurately by considering differences in customer contact and outdoor activities. 
Table 4

Results of multiple regression analysis with physical proximity as the dependent variable

\begin{tabular}{|c|c|c|c|c|c|c|}
\hline Variable & $\beta$ & & & & & \\
\hline Adverse Conditions & & & - & & - & \\
\hline Leadership & & & - & & - & \\
\hline Information Processing & -0.096 & ** & - & & -0.158 & ** \\
\hline Response to Aggression & 0.460 & ** & - & & 0.155 & ** \\
\hline Mechanical Movement & -0.099 & ** & - & & & \\
\hline Autonomy & & & - & & - & \\
\hline Communication with the Outside & -0.254 & ** & - & & -0.421 & ** \\
\hline Horizontal Teamwork & 0.288 & ** & - & & 0.250 & ** \\
\hline${ }^{\mathrm{a}}$ Teamwork & - & & -0.179 & ** & - & \\
\hline${ }^{\mathrm{a} C}$ ustomer & - & & 0.595 & ** & 0.565 & ** \\
\hline${ }^{\text {aP Presence }}$ & - & & 0.333 & ** & - & \\
\hline${ }^{\mathrm{b}}$ Remote Working & & & & & -0.199 & ** \\
\hline $\mathrm{R}^{2}$ & 0.322 & & 0.295 & & 0.494 & \\
\hline Adjusted $\mathrm{R}^{2}$ & 0.319 & & 0.293 & & 0.491 & \\
\hline $\mathrm{F}$ & 91.288 & ** & 134.161 & ** & 155.435 & ** \\
\hline
\end{tabular}

\section{Note}

The lower left box is one standard deviation lower than the average value; the upper right box is one standard deviation higher than the average value.

Figure 1 shows the correlation between response to aggression and physical proximity-the lower left box indicates that the values of both are one standard deviation lower than the average value, while the upper right box indicates that they are one standard deviation higher than the average value. Appendices $\mathrm{A} 1$ and A2 include the occupations from the two boxes for each variable. A1 comprises the so-called "experts," while in A2, there are elementary/middle school and special education teachers, therapists, technicians, nurses, restaurants' and entertainment facilities' staff, travel/postal service clerks, flight/transportation attendants, etc.

\section{Discussion}

The purpose of this study was to find variables that correlate with physical proximity via an exploratory method. The factors extracted by performing exploratory factor analysis were adverse conditions, leadership, information processing, response to aggression, mechanical movement, autonomy, communication with the outside, and horizontal teamwork. Of these, adverse conditions, response to aggression, and horizontal teamwork were shown to have a positive correlation with physical proximity, and information processing, autonomy, and communication with the outside were shown to have a negative correlation with it. In addition, as a result of multiple regression analysis, the model in which information processing, response to aggression, mechanical movement, autonomy, communication with the outside, and horizontal teamwork were simultaneously introduced showed an adjusted R-squared value above 0.3. Above all, response to aggression was shown to be the most important factor affecting physical proximity.

In parallel, we verified the relationship between the three variables shown by Koren \& Petö ${ }^{6}$ and physical proximity, and found that customer had a significantly larger correlation than teamwork and presence. It was also shown that the problem of multicollinearity occurred and the teamwork coefficient was reversed when the three were applied to the regression equation at the same time; it thus became clear that some caution is required in use. On the other hand, the variables that combine those of Koren \& Petö 6 into one, or the Remote Working Index of Dingel \& Neiman ${ }^{4}$ showed a significant correlation with physical proximity, avoiding the problem of multicollinearity. However, their adjusted R-squared value was below 0.2 , which indicates that the model's explanatory power is unsatisfactory. In an attempt, we added customer, ${ }^{6}$ which represents contact with the customer, and remote working, ${ }^{4}$ which represents a small amount of outdoor activity, to our multiple regression model comprising five variables. As a result, although the partial regression coefficient was distorted due to the problem of multicollinearity, it was significant in four of the five variables, including response to aggression, in addition to customer and remote working. This result shows that the model presented in this study is significant even after controlling the variables of the previous studies. At the same time, it suggests that this mixed model can be used with higher accuracy when predicting the feasibility of social distancing in the workplace.

In the model presented herein, in addition to response to aggression, horizontal teamwork showed a positive correlation, while information processing, mechanical movement, and communication with the outside showed a negative correlation, with physical proximity. Those who need a response to

Page 9/12 
aggression or horizontal teamwork and engage in little information processing, mechanical movement, or communication with the outside will have the most difficulty in maintaining social distancing.

\section{Implication}

In the study by Koren \& Pető, ${ }^{6}$ a model was constructed assuming that one of the three factors influencing social distancing is teamwork; its results, however, contradict with those of the current study which showed that response to aggression has a greater influence on physical proximity than horizontal teamwork does. This means that while some horizontal teamwork is possible even in the virtual world, ${ }^{16,17}$ it is difficult to respond remotely and on the spot when dealing with people who seek confrontation by getting angry or being offensive. This means that it is necessary to face and deal with them directly. Unfortunately, it seems unlikely that science and technology will replace aggressive human contact. For instance, in the field of robot development, it has been pointed out that the most difficult task is to operate in an unstructured environment that assumes contact with humans. ${ }^{18}$

In this study, to eliminate arbitrariness as much as possible, we have presented a model for determining physical proximity by performing exploratory factor analysis based on certain rules, extracting eight factors, and conducting multiple regression analysis. The types of jobs where it is difficult to avoid physical proximity because of response to aggression include those of elementary/middle school and special education teachers, therapists, technicians, nurses, restaurants' and entertainment facilities' staff, travel/postal service clerks, and flight/transportation attendants. For such occupations, it may not be easy to practice social distancing by switching to remote work, so it is necessary to devise and implement protective measures that can curb the spread of infection even when such professionals are in close proximity to people. In reality though, the occupations where people cannot suppress their emotions during the process of contacting customers are not limited to those mentioned above. For example, the results of an interview survey showed that nurses experience aggression more from their own colleagues rather than from patients. ${ }^{19}$ Therefore, the results of this study suggest that the existence of such people may make physical proximity, which can otherwise be avoided through remote work, inevitable. Learning how to control one's emotions well, ${ }^{20}$ and building a mechanism of reciprocity by increasing social capital to suppress selfish thinking, ${ }^{21,22}$ etc. are also considered to be successful in the practice of social distancing. At the same time, it should be noted that member aggression often arises from mistreatment in the organization. For example, previous studies report that perceived injustice ${ }^{23}$ or unfair treatment by bosses ${ }^{24}$ increases employee aggression. Therefore, management ingenuity, such as devising a method of providing reasonable feedback to employees, should also help increase the feasibility of social distancing.

\section{Limitation}

This paper exploratively extracted the factors that are the variables used in regression analysis, using the average values by occupation from the attitude survey data recorded on the US occupational information site $0 *$ NET. Therefore, if the primary data before being aggregated by occupation can be obtained, and the results of this study can be verified, its significance will be immense. Physical proximity, used as the dependent variable in the analysis, is a variable based on the questionnaire survey results and may differ from the actual proximity. Therefore, it is also important to verify the analytical model of this study after measuring the actual proximity using GPS location information, etc.

\section{Conclusion}

COVID-19 is still raging, and hence, social distancing has attracted attention as a measure to prevent the spread of infection; however, some occupations find it difficult to practice it. Therefore, in previous studies, the scale of factors determining social distancing was developed; there was, however, lack of clarity on how to select the items among them, and it seemed to be somewhat arbitrary. In response, this study extracted eight factors by performing exploratory factor analysis based on certain rules while eliminating arbitrariness as much as possible: adverse conditions, leadership, information processing, response to aggression, mechanical movement, autonomy, communication with the outside, and horizontal teamwork. Of these, adverse conditions, response to aggression, and horizontal teamwork had a positive correlation with physical proximity, and information processing, mechanical movement, autonomy, and communication with the outside had a negative correlation with it. Furthermore, multiple regression analysis showed that response to aggression, not the mere teamwork assumed in previous studies, had the greatest influence on physical proximity. Therefore, this study indicates that it is necessary to constrain (i.e., restrict) aggression in the workplace to maintain social distancing.

\section{Abbreviations}

COVID-19

coronavirus disease

\section{Declarations}

\section{Ethics approval and consent to participate}

This work did not require ethical approval and consent to participate because we used anonymous information that is open to the public on $\mathrm{O}$ NET, a US occupational information site.

\section{Consent for publication}

Not applicable.

\section{Availability of data and material}


Data are available from the authors upon reasonable request.

\section{Competing interests}

The authors have no competing interests to declare.

\section{Funding}

This work was supported by JSPS KAKENHI (Grant Number JP17H06151).

\section{Authors' contributions}

K.K. performed the data analysis, wrote the main manuscript text, and prepared the figures and tables. Y.Y. conducted the supervisory work and was responsible for funding acquisition and project administration. All authors reviewed and edited the manuscript.

\section{Acknowledgements}

An earlier version of this treatise is published on the following preprint server: https://arxiv.org/abs/2008.04131

\section{References}

1. Johns Hopkins University \& Medicine. COVID-19 Dashboard. 2020. https://coronavirus.jhu.edu/map.html Accessed 8 Aug 2020.

2. World Health Organization. Coronavirus disease (COVID-19) advice for the public. 2020. https://www.who.int/emergencies/diseases/novel-coronavirus2019/advice-for-public Accessed 8 Aug 2020.

3. Crowley F, Doran J. Covid-19, occupational social distancing and remote working potential in Ireland (No. SRERCWP2020-1). SRERC Working Paper Series. Retrieved from https://www.econstor.eu/handle/10419/218897 Accessed 8 Aug 2020.

4. Dingel JI, Neiman B How many jobs can be done at home? Journal of Public Economics, 2020;189. https://doi.org/10.3386/w26948

5. Hatayama M, Viollaz M, Winkler H. Jobs' Amenability to Working from Home: Evidence from Skills Surveys for 53 Countries. Policy Research Working Paper. 2020;9241, World Bank. https://doi.org/10.1596/1813-9450-9241

6. Koren M, Pető R. Business disruptions from social distancing. arXiv preprint. 2020;arXiv:2003.13983. Retrieved from https://arxiv.org/abs/2003.13983 Accessed 8 Aug 2020.

7. Stevens JP. Applied multivariate statistics for the social sciences (2nd edition). Hillsdale; 1992.

8. Purvanova RK, Bono JE. Transformational leadership in context: Face-to-face and virtual teams. The Leadership Quarterly. 2009;20(3):343-357. https://doi.org/10.1016/j.leaqua.2009.03.004

9. De Clercq D, Belausteguigoitia I. Reducing the harmful effect of role ambiguity on turnover intentions. Personnel Review. 2017;46(6):1046-1069. https://doi.org/10.1108/PR-08-2015-0221

10. Jong J. The role of performance feedback and job autonomy in mitigating the negative effect of role ambiguity on employee satisfaction. Public Performance \& Management Review. 2016;39(4), 814-834. https://doi.org/10.1080/15309576.2015.1137771 Accessed 8 Aug 2020.

11. den Brock P, Levy J, Breckelmans M, Wubbels T. The Effect of Teacher interpersonal Behavior on Student' Subject specific Motivation. Journal of Classroom Interaction. 2005;40(2):20-33. Retrieved from https://www.jstor.org/stable/23870661 Accessed 8 Aug 2020.

12. Cortina JM. What is coefficient alpha? An examination of theory and applications. Journal of Applied Psychology. 1993;78(1), 98-104. https://doi.org/10.1037/0021-9010.78.1.98

13. Taber KS. The use of Cronbach's alpha when developing and reporting research instruments in science education. Research in Science Education. 2018;48(6):1273-1296. https://doi.org/10.1007/s11165-016-9602-2

14. van Griethuijsen RA, van Eijck MW, Haste H, den Brok PJ, Skinner NC, Mansour N, Gencer A S, BouJaoude S. Global patterns in students' views of science and interest in science. Research in Science Education. 2015:45(4):581-603. https://doi.org/10.1007/s11165-014-9438-6

15. Cohen J. Statistical power analysis for the behavioral sciences (2nd ed.), Erlbaum; 1988.

16. Krumm S, Kanthak J, Hartmann K, Hertel G. What does it take to be a virtual team player? The knowledge, skills, abilities, and other characteristics required in virtual teams. Human Performance. 2016;29(2):123-142. https://doi.org/10.1080/08959285.2016.1154061

17. Painter G, Posey P, Austrom D, Tenkasi R, Barrett B, Merck B. Sociotechnical systems design: coordination of virtual teamwork in innovation. Team Performance Management. 2016;22(7/8): 354-369. https://doi.org/10.1108/TPM-12-2015-0060

18. Mori N. Recent status on robot industry in Japan: Focusing on service robots. Japan Society for the Promotion of Machine Industry Economic Research Institute Essay. 2020;8. Retrieved from http://www.jspmi.or.jp/system/file/6/89/202002essey08_mori.pdf

19. Farrell GA. Aggression in clinical settings: Nurses' views. Journal of Advanced Nursing. 1997;25(3):501-508. https://doi.org/10.1046/j.13652648.1997.1997025501.x

20. Denson TF, Capper MM, Oaten M, Friese M, Schofield TP. Self-control training decreases aggression in response to provocation in aggressive individuals. Journal of Research in Personality. 2011;45(2), 252-256. https://doi.org/10.1016/j.jp.2011.02.001

21. Kokubun K. Social capital may mediate the relationship between social distance and COVID-19 prevalence. arXiv preprint. 2020;arXiv:2007.09939. Retrieved from https://arxiv.org/abs/2007.09939 Accessed 8 Aug 2020. 
22. Kokubun K, Ino Y, Ishimura K. Social capital and resilience make an employee cooperate for coronavirus measures and lower his/her turnover intention. arXiv preprint. 2020.arXiv:2007.07963. Retrieved from https://arxiv.org/abs/2007.07963 Accessed 8 Aug 2020.

23. Beugré CD. Understanding injustice-related aggression in organizations: A cognitive model. The International Journal of Human Resource Management. 2005;16(7):1120-1136. https://doi.org/10.1080/09585190500143964

24. Neuman JH, Baron RA. Workplace violence and workplace aggression: Evidence concerning specific forms, potential causes, and preferred targets. Journal of Management. 1998;24(3), 391-419. https://doi.org/10.1177/014920639802400305

\section{Figures}

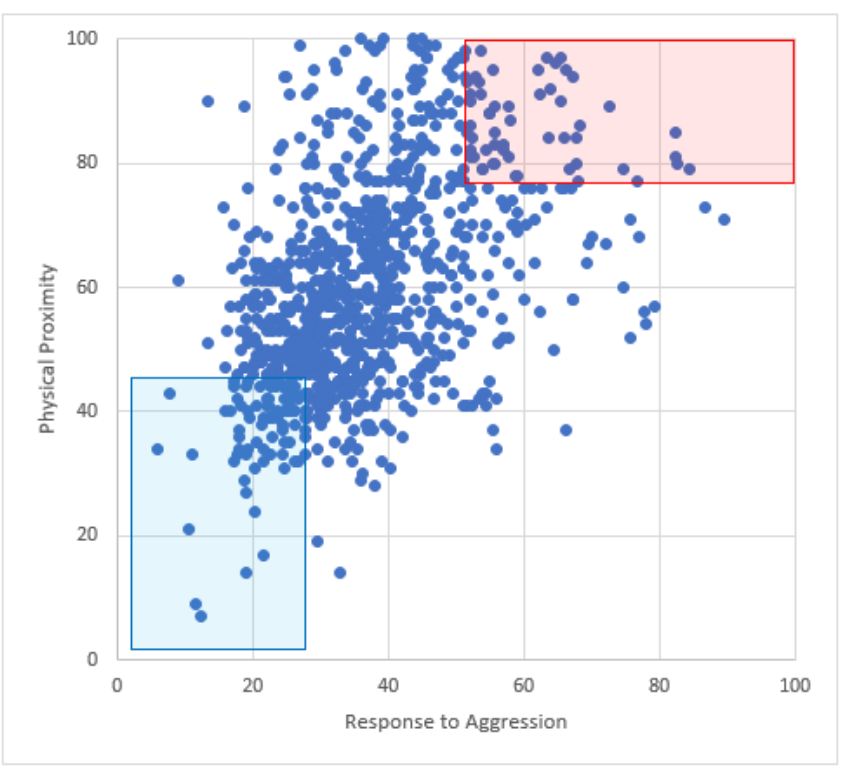

Figure 1

Scatter plot showing the relationship between response to aggression and physical proximity 